To the Editors:

\title{
Serum carotenoids in eight Sri Lankan children
}

Vitamin A deficiency is known to occur in Sri Lanka [1]. Hence people are advised to consume foods containing carotenoids.

Blood samples were obtained from 8 children (age range 9-30 months) with yellow pigmentation of the skin, especially their palms and soles. Ethical committee approval and informed consent were obtained before taking blood samples. These children had consumed excess of carrot, papaw and pumpkin over a period of time that varied from 4 to 17 months, beginning at 3-7 months of the age. These foods were given as often as 3 times a day. Their serum TSH levels were normal. Blood (2 ml) was extracted into hexane and analysed by HPLC for carotenoids and vitamin A [2].

\section{Results and discussion}

In 6 cases, the carotenoid spectrum and HPLC carotenoid profile showed the presence of $\beta$-carotene (9.9$35.7 \mu{\mathrm{g} . \mathrm{dl}^{-1}}^{-1}$, mono-hydroxy carotenoid metabolites and $\beta$-cryptoxanthin collectively $\left(5.3-48.5 \mu \mathrm{g} . \mathrm{dl}^{-1}\right)$ and 6-8 di, tri and poly-hydroxy carotenoid metabolites (22.5-282.1 $\left.\mu \mathrm{g} . \mathrm{dl}^{-1}\right)$. In all children vitamin A levels were normal (32-61 $\left.\mu \mathrm{g} . \mathrm{dl}^{-1}\right)$. This appeared to be the typical pattern of hypercarotenaemia and this is the typical carotenoid metabolic pattern [3]. These metabolites were not found in controls. In the other 2 cases there was a departure from what appeared to be normal. In one, the baby had been fed with excess of carrot, papaw, pumpkin and mango, and showed a low $\beta$-carotene $\left(3.5 \mu \mathrm{g} . \mathrm{dl}^{-1}\right)$, no $\beta$ cryptoxanthin and mono-hydroxy metabolites but a normal level of di, tri and poly-hydroxy derivatives $\left(128.2 \mu \mathrm{g} \cdot \mathrm{dl}^{-1}\right)$. This may be due to discontinuation of high carotenoid diet before venesection. In this baby the vitamin A level was high $\left(75.2 \mu \mathrm{g} . \mathrm{dl}^{-1}\right)$, but still lower than the upper level of the normal $\left(81 \mu \mathrm{g} \cdot \mathrm{dl}^{-1}\right)$. The same blood sample case showed another sharp peak at lower retention time to vitamin A. This may correspond to retinoic acid. In the other baby there was very high $\beta$-carotene content $(212.3$ $\mu$ g.dl $\left.{ }^{-1}\right), \beta$-cryptoxanthin $\left(49.3 \mu \mathrm{g} . \mathrm{dl}^{-1}\right)$, but no normal di, tri and poly-hydroxy carotenoid metabolites. Instead there was a more hydrophobic metabolite $\left(343.9 \mu \mathrm{g} . \mathrm{dl}^{-1}\right)$ than $\beta$ cryptoxanthin. This is probably due to the formation of either an abnormal epoxide that cannot be hydroxylated further by liver enzymes or the absence of an enzyme involved in hydroxylation.

\section{Acknowledgment}

We thank IPICS for funding the Sri: 07 grant.

\section{References}

1. Medical Research Institute Sri Lanka (1998) Report of the survey on vitamin A deficiency status of children in Sri Lanka 1995/96. Publ. UNICEF.

2. Bieri JG, Tolliver TJ, Catignani GL. Simultaneous determination of $\alpha$-tocopherol and retinol in plasma or red cells by high-pressure liquid chromatography. American Journal of Clinical Nutrition 1979; 32: 43-9.

3. Khachik F, Spangler CJ, Smith Jr JC, Canfield LM, Steck A, Pfander H. Identification, quantification and relative concentrations of carotenoids and their metabolites in human milk and serum. Analytical Chemistry 1997; 69: 1873-81.

\footnotetext{
A M B Priyadarshani ${ }^{1}$, Sanath P Lamabadusuriya ${ }^{2}$, T R S Seneviratne ${ }^{3}$, E R Jansz ${ }^{1}$ and H Peiris ${ }^{1}$

${ }^{1}$ Department of Biochemistry, University of Sri Jayewardenepura, Nugegoda, Sri Lanka. ${ }^{2}$ Department of Paediatrics, University of Colombo, Sri Lanka. ${ }^{3}$ Department of Paediatrics, University of Sri Jayewardenepura, Nugegoda, Sri Lanka.

Correspondence: HP, Tel: 011 2803578. Received 15 August 2007, and revised version accepted 11 February 2008. Competing interests: none declared.
} 